\title{
In memory of Dr. Kary Mullis
}

\author{
Massimo Cocchi \\ President of the Italian Society for Experimental Biology (Società Italiana di Biologia Sperimentale - SIBS), Italy
}

\section{To Kary Mullis}

It was 2000 when I met Terrance Leighton (Terry) in the magnificent setting of Venice where I attended a conference on selenium.

I was there because a dear friend, Sebastiano Venturi, had asked me, with strong conviction, to present a work/hypothesis which we had just published about iodine/selenium/omega/3 fatty acid relationship, an example of biological cooperation.

I've always been dubious to think that things happen by chance and not for a design of which we never know, at first, the randomness, then to understand and fully interpret its meaning and the reason why.

The fact is that I met Terry and, during a long chat, sitting on the edge of the wall of the cloister of the island of San Giorgio at the Cini Foundation, I met Kary Mullis.

I met Kary Mullis through the exciting words of Terry, who made me the proposal to invite him for a conference in Italy.

Frankly, I wondered if it was a joke or if I could really consider the proposal.

In short, the event materialized in its preliminary stages, the choice fell on Pennabilli, where my friend Sebastiano lives and where Tonino Guerra, Federico Fellini's historical friend and collaborator, also lived.

It seemed the ideal setting for a mix of science, culture and art in the scientific history of humanity, He, Kary Mullis, the man who had discovered, better, the man who had gone to the essence of life by reproducing DNA.
The fateful day arrived and, in the evening, a small bus disembarked at Pennabilli Kary, his wife Nancy and Nancy's sister, Linda.

Kisses and pleasantries and we all sit at the table, in Sebastiano's garden, a table full of crescentine, Carpegna ham, sizzling meat on the embers and Sangiovese.

I had done a kind of miracle.

There, in Pennabilli we set, Kary and I, the bases of a friendship that will last until August 7th 2019, when the picture of life will show the last brushstroke.

In my arguing that time and death do not exist in a paradox that I failed, as we have done for so many other things, to discuss with Kary, the tragic moment of the end of a life story has arrived.

An end to the dialogue but certainly not of the example and the teaching.

Example and teaching are the icons Kary left me.

Example because he represented the freedom of genius, the teaching because he has shown me that, whoever you are or whatever you have done, you have to cultivate humility.

About twenty years have passed and my Nobel, which today I would not like to have so much has diminished in importance, were Kary's words when he said: This research will revolutionize the world of medicine, philosophy and religion.

$\mathrm{He}$ understood that the research I had done was able to enter the intimacy of human consciousness through a molecular game.

Kary, I don't know if one day we'll meet again, but if it is, we will certainly drink a glass of good

Sangiovese as we have done so many times.

Your Massimo
Correspondence: Massimo Cocchi, President of the Italian Society for Experimental Biology (Società Italiana di Biologia Sperimentale SIBS), Italy.

E-mail: massimo.cocchi@unibo.it

Received for publication: 23 August 2019.

Accepted for publication: 23 August 2019.

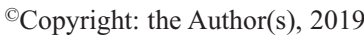

Licensee PAGEPress, Italy

Journal of Biological Research 2019; 92:8513

doi:10.4081/jbr.2019.8513

This article is distributed under the terms of the Creative Commons Attribution Noncommercial License (by-nc 4.0) which permits any noncommercial use, distribution, and reproduction in any medium, provided the original author(s) and source are credited. 